\title{
Evaluation of the Nutritional Value of Selected Banana Varieties Grown in Sri Lanka
}

\author{
Harshani Nadeeshani ${ }^{1}$, Gamini Samarasinghe ${ }^{2}$, Swarna Wimalasiri ${ }^{1}$, Renuka Silva ${ }^{3}$, \\ Terrence Madhujith ${ }^{1}$ \\ ${ }^{1}$ Department of Food Science and Technology, Faculty of Agriculture, University of \\ Peradeniya, Sri Lanka \\ ${ }^{2}$ Plant Genetic Resource Center, Gannoruwa, Sri Lanka \\ ${ }^{3}$ Department of Applied Nutrition, Faculty of Livestock, Fisheries and Nutrition, \\ Wayamba University of Sri Lanka, Sri Lanka \\ Corresponding Author's email: nadeeshanihr@gmail.com
}

\begin{abstract}
There are nearly 30 varieties of banana (Musa spp.) are grown in Sri Lanka. Some of them are indigenous while the others are exotic. In the present study, five banana varieties commonly grown in Sri Lanka, namely Seeni kesel, Ambul kesel, Kolikuttu, Rathambala and Puwalu were evaluated for their nutritional composition. Samples of each banana variety were collected from different geographical locations of the country representing all agro-climatic zones. Healthy and undamaged fruits were collected, cleaned and air dried at $45{ }^{\circ} \mathrm{C}$, pooled and stored at $4{ }^{\circ} \mathrm{C}$ for further analysis. Proximate and mineral composition of each sample were determined and presented on fresh weight basis. Moisture, ash, crude fat, crude protein and total carbohydrate contents were determined using AOAC methods. The moisture content ranged between $67.24 \pm 2.19$ and $73.14 \pm 0.56 \%$ while the crude protein content ranged between $1.20 \pm 0.02$ and $1.41 \pm 0.04 \%$. The corresponding ranges for ash, total carbohydrates and crude fat were $1.18 \pm 0.05-3.89 \pm 0.38 \%, 13.46 \pm 0.36-26.46 \pm 0.36 \%$ and $0.14 \pm 0.00-0.20 \pm 0.02 \%$, respectively. All varieties of banana contained $\mathrm{Ca}, \mathrm{Mg}, \mathrm{K}, \mathrm{Na}, \mathrm{Fe}, \mathrm{Ba}, \mathrm{Zn}$, $\mathrm{Mn}, \mathrm{Cu}, \mathrm{Sr}, \mathrm{Rb}$ and $\mathrm{Al}$ in considerable quantities while $\mathrm{Cr}, \mathrm{Co}, \mathrm{Ni}, \mathrm{Se}, \mathrm{Mo}, \mathrm{V}, \mathrm{Ga}, \mathrm{Cd}, \mathrm{Bi}, \mathrm{As}, \mathrm{Li}$ and Be were detected in minute quantities. Comparatively, Seeni kesel was found to be the superior $(\mathrm{p}<0.05)$ source of essential mineral elements. Among highly concerned heavy metals, the highest $\mathrm{Cr}$ and Cd contents $(\mathrm{p}<0.05)$ were found in Seeni kesel while Puwalu contained the highest As content, which might be resulted by malpractices of cultivation, artificial ripening, packaging and storage.
\end{abstract}

Keywords: Crude fat, crude protein, mineral composition, proximate composition

\section{Introduction}

Diets rich in fruits have historically held a fundamental place in dietary guidance as a consequence of their concentrated amounts of vitamins, especially vitamins $\mathrm{C}$ and $\mathrm{A}$, minerals, such as calcium, magnesium, iron and phosphorus and phytochemicals, particularly antioxidants. Intake of fruits and vegetables is an important indicator of diet quality and protective factors against certain chronic diseases such as cardiovascular disease, cancer, diabetes, Alzheimer disease, cataracts, and age-related functional decline (Willett, 1995; Temple, 2000).

Analysis of nutritional composition of food is crucial to provide nutrient data at thame aggregate level, and strive for year-round, nation-wide mean values, with all compositional differences related to agro-ecological zone, seasonality and biodiversity. Through compositional analysis, knowledge on the differences in nutritional value among fruits from different species and from varieties of the same species can be given to the professionals in health, nutrition, agriculture and environment for not misleading them in diet planning, food consumption surveys, nutrition and health policies and programs, agricultural policies and programs, etc. Recent data on nutritional value of Sri Lankan banana varieties are very scanty thus the importances of comparative analysis and reporting the composition of them have been a long felt need. Through compositional analysis, nutritionally more important varieties among others can be investigated. It is one of the vital type of studies 
since, intra-specific differences of fruits can be used as the base in mediating nutrient deficiency, nutrient adequacy and nutrient toxicity of a population in a country.

Banana (Musa spp.) is native to Southeast and South Asia and it is the most widely cultivated and consumed fruit in Sri Lanka. Moreover, it is the mostly produced and traded fruit in fresh form in the world. The wide variation in temperature, rainfall, topography and soils in Sri Lanka has offered a wide diversity of ecosystems resulting in a rich diversity of plant species throughout all agro-climatic zones. Consequently, Sri Lanka is encompasses 29 banana cultivars and two wild varieties. Among total land area under numerous fruit cultivations in Sri Lanka, banana claims 69 - 70\% (Ekanayake et al. 2001).

\section{Materials and Methods}

\section{Sample Collection and Preparation}

A total of $500 \mathrm{~g}$ of healthy, undamaged fruits of five banana varieties (Seeni kesel, Ambul kesel, Kolikuttu, Rathambala and Puwalu) were collected from seven agro-climatic zones of Sri Lanka separately, packed in polythene bags, labeled, placed in temperature controlled containers and transported to the laboratory without a delay.

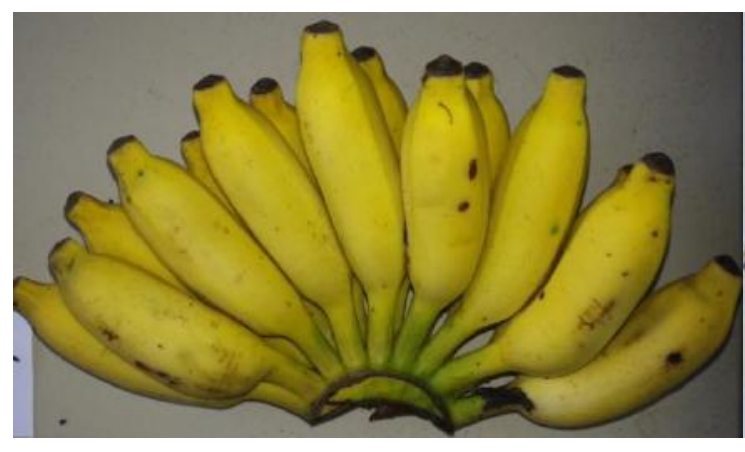

Figure 1 Ambul kesel variety

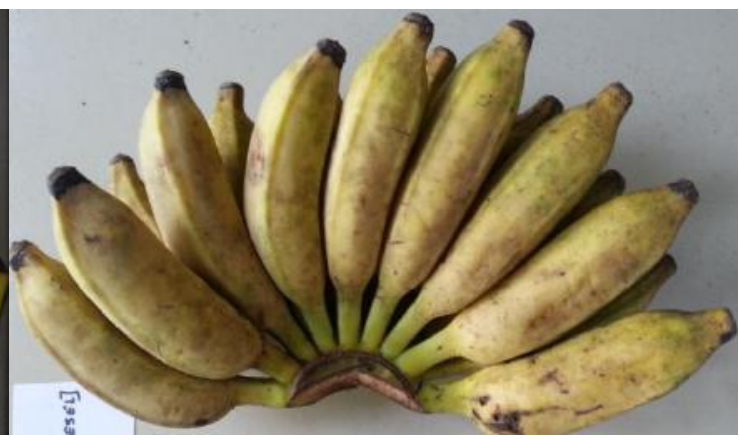

Figure 2 Seeni kesel variety

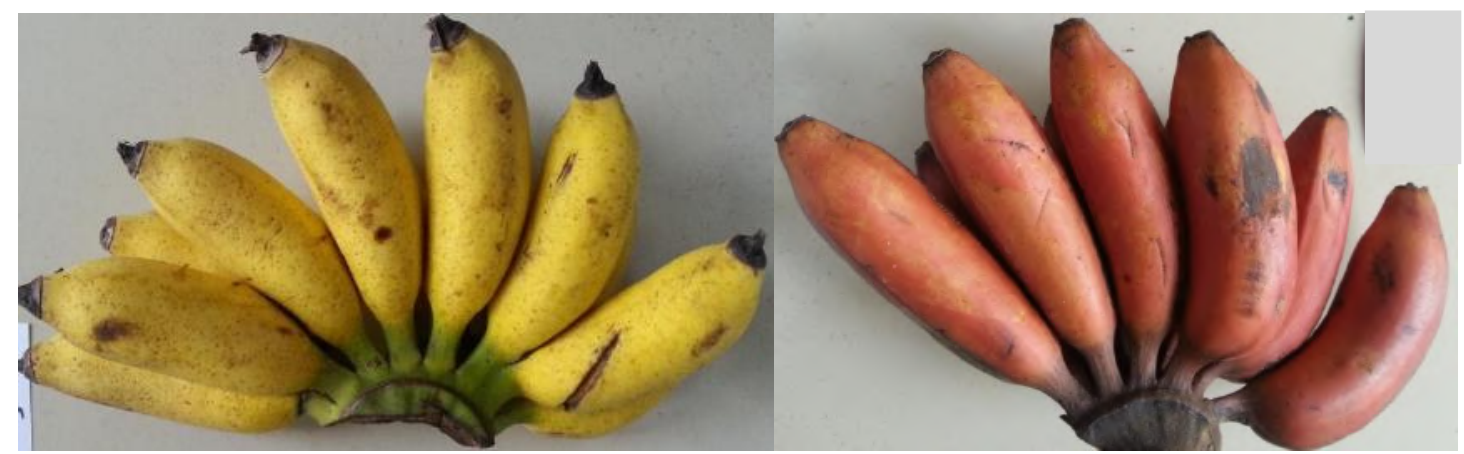

Figure 3 Kolikuttu variety

Figure 4 Rathambala variety 


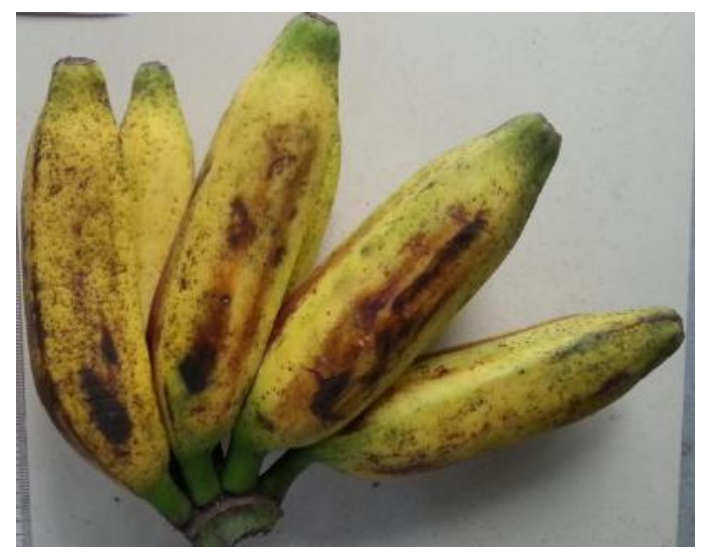

Figure 5 Puwalu variety

The samples were photographed, identified and authenticated by taxonomists in the Plant Genetic Resources Centre, Sri Lanka. They were sorted, cleaned appropriately and oven dried at $45^{\circ} \mathrm{C}$ (Phoenix ${ }^{\mathrm{TM}}$, Germany). The oven dried samples from each agro-climatic zone were disintegrated in a stainless steel grinder (Apex ${ }^{\mathrm{TM}}$, India), pooled separately in similar quantities and homogenized assuring uniform distribution to prepare the working samples. Oven dried samples were stored at $4{ }^{\circ} \mathrm{C}\left(\mathrm{LG}^{\mathrm{TM}}\right.$, Japan) for further analyses.

\section{Proximate Analysis}

Moisture content of fresh samples and crude protein, fat and ash contents of oven dried samples were determined according to the AOAC (2000). The crude protein and crude fat contents were determined using Kjeldahl method (Digester - VELP Scientifica ${ }^{\mathrm{TM}}$, DK 6, Italy and Distillation unit - VELP Scientifica ${ }^{\mathrm{TM}}$, UDK 129 , Italy) and soxhlet extraction methods respectively. The moisture content was determined by drying the sample to a constant weight at $105^{\circ} \mathrm{C}$ in a forced air-oven (SIBATA ${ }^{\mathrm{TM}}$, SPF-600, Japan). The ash content was determined using weight loss method by muffle furnace (HOBERSAL ${ }^{\mathrm{TM}}$, HP-150, Spain). All chemicals used (petroleum ether, potassium sulfate, copper sulfate, boric acid, sulphuric acid, sodium hydroxide, bromocresol green and methyl red mixed indicator, hydrochloric acid and Devarda's alloy were of analytical grade purchased from Sigma-Aldrich ${ }^{\mathrm{TM}}$, USA.

\section{Determination of Total Carbohydrate Content}

The total carbohydrate content was determined according to the method described in AACC 2003 (American Association of Cereal Chemists). A sample $(100 \mathrm{mg})$ was acid-hydrolyzed in a boiling water bath for three hours with $5 \mathrm{~mL}$ of $2.5 \mathrm{~N} \mathrm{HCl}$. Then the sample was cooled to room temperature, neutralized with sodium carbonate until the effervescence ceased, made up the volume to $100 \mathrm{~mL}$ and centrifuged at $4000 \mathrm{rpm}$ for 10 minutes. A sample $(0.1 \mathrm{~mL})$ of the supernatant collected was pipetted out and volume was made up to $1 \mathrm{~mL}$ with distilled water. Blank was set with $1 \mathrm{~mL}$ of distilled water. Five percent Phenol solution $(1 \mathrm{~mL})$ and $5 \mathrm{~mL}$ of $96 \%$ sulphuric acid were added into each tube, the contents were shaken for 10 minutes and placed in a water bath at $25-30{ }^{\circ} \mathrm{C}$ for $20 \mathrm{~min}$. All analyses were carried out in triplicates and absorbance was taken using UV/Visible microplate spectrophotometer (Thermo Scientific ${ }^{\mathrm{TM}}$, Genesys $10 \mathrm{~S}$, UK) at $490 \mathrm{~nm}$. Total carbohydrate contents were calculated as percentages using the glucose standard calibration curve $(0.0028$ $0.0143 \mathrm{ppm}$ ). Absorbance of the blank was taken and necessary corrections were made in calculations. All chemical reagents used were of analytical grade and purchased from Sigma-Aldrich ${ }^{\mathrm{TM}}$, USA. 


\section{Quantification of the Mineral Content}

Mineral analysis by ICP-MS was performed according to the method described by de la Rocha (2009) with some minor modifications. Acid digestion of the oven dried samples $(0.2 \mathrm{~g})$ was performed with $10 \mathrm{~mL}$ of nitric acid $(65 \% \mathrm{w} / \mathrm{v})$ using a commercial high-pressure laboratory microwave oven $\left(\mathrm{CEM}^{\mathrm{TM}}\right.$ Corporation, BR601050, USA), operating by setting the program for $15 \mathrm{~min}$ ramping time, 10 min holding time during digestion at 180 ${ }^{\circ} \mathrm{C}$ and 15 min cooling time. Digested samples were transferred to a $50 \mathrm{~mL}$ volumetric flask, made up to volume with de-ionized water, filtered and stored at $4{ }^{\circ} \mathrm{C}$. Test solutions contained $100 \mu \mathrm{g} / \mathrm{L}$ of $\mathrm{Rh}$ and $\mathrm{Re}$, which were used as internal standards to correct instrumental drift and possible matrix effects.

For calibration, multi-elemental standard solutions were prepared with the following concentrations: $0,5,10,30$ and $50 \mathrm{mg} / \mathrm{L}$ for $\mathrm{Na}, \mathrm{Mg}, \mathrm{K}, \mathrm{Al}, \mathrm{Mn}, \mathrm{Zn}, \mathrm{Fe}, \mathrm{Rb}, \mathrm{Sr}$ and $\mathrm{Ba}$; and 0, 0.8, 3.0 and 10.0, $20.0 \mu \mathrm{g} / \mathrm{L}$ for $\mathrm{Cr}, \mathrm{Co}, \mathrm{Ni}$, $\mathrm{Cu}, \mathrm{As}, \mathrm{Se}, \mathrm{Li}, \mathrm{Be}, \mathrm{V}, \mathrm{Ga}, \mathrm{Mo}, \mathrm{Cd}$ and Bi. Analysis was carried out in triplicates. Inductively Coupled Plasma Mass Spectrometer (iCAPQ, Thermo Scientific, UK) was used for analytical determinations. Operating conditions of the ICP-MS for the analysis of the leafy vegetable samples are shown in Table 1. All analytical grade chemical reagents and multi-elemental standards used were purchased from Sigma-Aldrich ${ }^{\mathrm{TM}}$, USA.

Table 1 Operating conditions for ICP Mass Spectrometer

\begin{tabular}{ll}
\hline Parameter & Value \\
\hline Auto Sampler & CETAC ASX-560 \\
\hline Plasma power & $1550 \mathrm{~W}$ \\
\hline Cool gas flow & $14 \mathrm{~L} / \mathrm{min}$ \\
\hline Auxiliary gas flow & $0.65 \mathrm{~L} / \mathrm{min}$ \\
\hline Sample cone & Nickel, $1 \mathrm{~mm}$ orifice diameter \\
\hline Skimmer cone diameter & Nickel, $0.75 \mathrm{~mm}$ orifice \\
\hline Dowell time & $10 \mathrm{~ms}(40 \mathrm{~ms}$ for Se, As $)$ \\
\hline RSD (3 replicates) typical & $<0.1 \mathrm{ppb}$ \\
\hline Sample flow & $0.4 \mathrm{~mL} / \mathrm{min}$ \\
\hline
\end{tabular}

Elements with the highest isotopic abundance were selected as analytical mass. For the within-run assessment, the accuracy and precision of the assays were examined in a single run, with six replicate samples. For the between-run assessment, TM 25.4 (Environment Canada) for water was analyzed as certified reference material which covered the range of the elements studied such as $\mathrm{Al}, \mathrm{Cr}, \mathrm{Mn}, \mathrm{Co}, \mathrm{Ni}, \mathrm{Cu}, \mathrm{Zn}, \mathrm{As}$, and Se in six separate runs. Accuracy was defined as the percentage difference between the monitored concentration and the expected value $(\% \mathrm{D})$. Precision was expressed as the percentage of the variation coefficient $(\% \mathrm{CV})$. Acceptance criteria 
for accuracy and precision, derived from ICH (1996) rules, were as follows: the mean \%D and \%CV should not exceed $\pm 15 \% ; 75 \%$ of all samples had to be within $\pm 15 \%$ of expected concentrations. In the experiment, no more than one of the six samples within a given concentration could exceed $\pm 15 \%$ of their expected values.

\section{Statistical Analysis}

Data for all determinations were subjected to analysis of variance (ANOVA). Complete Randomized Design (CRD) was used as the experimental model and means of experimental data were compared by Duncan's multiple range test $(\mathrm{p}<0.05)$. Statistical analyses were conducted using the SAS Statistical Analysis System SAS/IML 14.1 (SAS Institute Inc., Cary, NC).

\section{Results and Discussion}

Names of banana varieties have been abbreviated as follows for the convenience of stating; Seeni kesel - SK, Ambul kesel - AK, Kolikuttu - KK, Rathambala - RT, and Puwalu - PU. Moisture contents were significantly higher in AK, KK, and RT that that in PU and SK in decreasing order $(\mathrm{p}<0.05)$. Crude protein contents of SK and KK were significantly higher than that of RT, AK and PU in decreasing order $(\mathrm{p}<0.05)$.

SK was comprised of the highest ash content followed in decreasing order by AK, KK, RT, and PU (p<0.05). PU and SK were contained higher crude fat contents that that in KK, AK and RT in decreasing order $(\mathrm{p}<0.05)$. SK was comprised of the highest total carbohydrate content followed in decreasing order by PU, KK, RT and AK $(\mathrm{p}<0.05)$. The values obtained from this study in comparison to those available in literature showed somewhat higher values for ash contents, fairly lower values for crude fat a contents and similar values for moisture and total carbohydrate contents with that reported by Hettiaratchi et al. (2011) who analyzed Kolikuttu, Seeni kesel and Embul kesel varieties. Deraniyagala et al. (1994) determined total carbohydrate contents of Kolikuttu, Anamalu and Embul kesel varieties resulting somewhat higher values than the present study.

These dissimilarities in nutritional composition among various studies may be come up due to the differences in farming practices, established environmental conditions and age of plants at harvest which affects their genetic composition. Recommended Dietary Allowance (RDA) of macronutrients can be compared with macronutrient contents of banana assuming complete digestion and absorption. RDA of total digestible carbohydrates for a person aged 19 to above 70 years is $130 \mathrm{~g}$ per day according to Institute of Medicine, US (2005) and the requirement could be met solely by intake of about $491 \mathrm{~g}, 966 \mathrm{~g}, 569 \mathrm{~g}, 964 \mathrm{~g}$ and $524 \mathrm{~g}$ of SK or AK or KK or RT or PU verities respectively per day assuming complete digestion and absorption. RDA of protein for a male aged 19 to above 70 years is $56 \mathrm{~g}$ per day while $46 \mathrm{~g}$ per day is for a female aged 19 to above 70 years (Institute of Medicine, US, 2005) and intake of $3-5 \mathrm{~kg}$ of studied banana varieties might complete the daily protein requirement solely which may indicate the low protein content of banana. According to The United States Department of Agriculture (USDA), if a person eats a diet of 2,000 calories per day, 44 - $77 \mathrm{~g}$ of total fat should be ingested daily. When compared with that recommendation, banana was obvious to be a poor source of fat.

Table 2 Proximate composition (\%) of selected banana varieties on fresh weight basis

\begin{tabular}{llllll}
\hline $\begin{array}{l}\text { Banana } \\
\text { Varieties }\end{array}$ & Moisture & Crude protein & Crude fat & Ash & Total Carbohydrate \\
\hline SK & $67.24 \pm 2.19^{\mathrm{c}}$ & $1.36 \pm 0.04^{\mathrm{a}}$ & $0.18 \pm 0.00^{\mathrm{a}}$ & $3.89 \pm 0.38^{\mathrm{a}}$ & $26.46 \pm 0.36^{\mathrm{a}}$ \\
\hline AK & $73.00 \pm 1.66^{\mathrm{a}}$ & $1.22 \pm 0.00^{\mathrm{bc}}$ & $0.14 \pm 0.00^{\mathrm{b}}$ & $1.43 \pm 0.02^{\mathrm{b}}$ & $13.46 \pm 0.36^{\mathrm{c}}$ \\
\hline KK & $72.06 \pm 2.33^{\mathrm{a}}$ & $1.41 \pm 0.04^{\mathrm{a}}$ & $0.17 \pm 0.01^{\mathrm{ab}}$ & $1.42 \pm 0.11^{\mathrm{b}}$ & $22.86 \pm 0.34^{\mathrm{b}}$ \\
\hline RT & $73.14 \pm 0.56^{\mathrm{a}}$ & $1.34 \pm 0.09^{\mathrm{ab}}$ & $0.14 \pm 0.00^{\mathrm{b}}$ & $1.41 \pm 0.03^{\mathrm{b}}$ & $13.49 \pm 1.41^{\mathrm{c}}$ \\
\hline PU & $70.21 \pm 0.38^{\mathrm{b}}$ & $1.20 \pm 0.02^{\mathrm{b}}$ & $0.20 \pm 0.02^{\mathrm{a}}$ & $1.18 \pm 0.05^{\mathrm{b}}$ & $24.82 \pm 0.89^{\mathrm{ab}}$ \\
\hline
\end{tabular}


Data represent the mean values \pm SD $(n=3)$ of three independent experiments. Means followed by the same letters in a column are not significantly different at $\mathrm{p}<0.05$ level by Duncan's multiple range test.

According to the mineral analysis, SK contained the highest amounts of $\mathrm{Mn}, \mathrm{Fe}, \mathrm{Cu}, \mathrm{Sr}, \mathrm{Ba}, \mathrm{Cr}, \mathrm{Co}, \mathrm{Ni}, \mathrm{Se}, \mathrm{Be}$, $\mathrm{Ga}$, Mo and $\mathrm{Cd}(\mathrm{p}<0.05)$. AK was encompassed of the highest amounts of $\mathrm{Al}, \mathrm{Zn}, \mathrm{Rb}$ and $\mathrm{Li}$ in contrast to the lowest amount of $\mathrm{Na}, \mathrm{Se}$ and $\mathrm{Be}$ it contained $(\mathrm{p}<0.05)$. The highest amounts of $\mathrm{Na}$ as well as the lowest amounts of $\mathrm{Mn}, \mathrm{Rb}, \mathrm{Cu}$ and $\mathrm{Cr}$ were found in $\mathrm{KK}(\mathrm{p}<0.05)$. RT was comprised of the highest quantities of $\mathrm{Mg}, \mathrm{K}, \mathrm{V}$ and $\mathrm{Bi}$ whilst it contained the lowest amounts of $\mathrm{Ca}, \mathrm{Zn}, \mathrm{Sr}, \mathrm{Ba}, \mathrm{Co}, \mathrm{As}, \mathrm{Li}$ and $\mathrm{Mo}(\mathrm{p}<0.05)$.

PU was resulted with the highest amounts of $\mathrm{Ca}$ and As plus the lowest amounts of $\mathrm{Mg}, \mathrm{K}, \mathrm{Fe}, \mathrm{Ni}, \mathrm{V}, \mathrm{Ga}$ and Cd. Minerals, though they are macro or micro-minerals required in the body for the maintenance of physiochemical processes essential to life. While minerals like $\mathrm{K}, \mathrm{Mg}, \mathrm{Ca}, \mathrm{Zn}, \mathrm{Fe}$ and $\mathrm{Cu}$ are considered essential, heavy metals like $\mathrm{Pb}, \mathrm{Cd}, \mathrm{Cr}, \mathrm{As}, \mathrm{Hg}$ and $\mathrm{Sn}$ are considered as a toxic contaminant and evidence of their requirements and necessities for the body is weak (Sobukola et al, 2010). As reported by Banadda et al. (2011), $\mathrm{Pb}$ and $\mathrm{Cd}$ which are residues from the polymerization process of polythene can migrate at high temperature and under long ripening and storage period. Since chemical ripening agents like carbide are used to generate heat, the high temperature needed for the heavy metals to migrate is provided (Ajayi and Mbah, 2007).

Calcium carbide treatment in fruit ripening is extremely hazardous because it contains traces of As and P, and once dissolved in water, it produces acetylene gas. As, $\mathrm{P}$ and acetylene gas may affect the different body organs and causes various health problems like headache, dizziness, mood disturbances, sleepiness, mental confusion, memory loss, cerebral edema, seizures and prolonged hypoxia (Asif, 2012). As shown in the Figure 6, significantly higher As content was observed in PU and moderate amounts of As were observed in SK, AK and $\mathrm{KK}(\mathrm{p}<0.05)$ indicating potential excess carbide usage. Moreover, the highest $\mathrm{Cd}$ and $\mathrm{Cr}$ contents were found in SK while AK, KK and RT contained moderate amounts which were not significantly different $(\mathrm{p}<0.05)$ pointing out a possible heavy metal contaminations during the artificial ripening attempts.

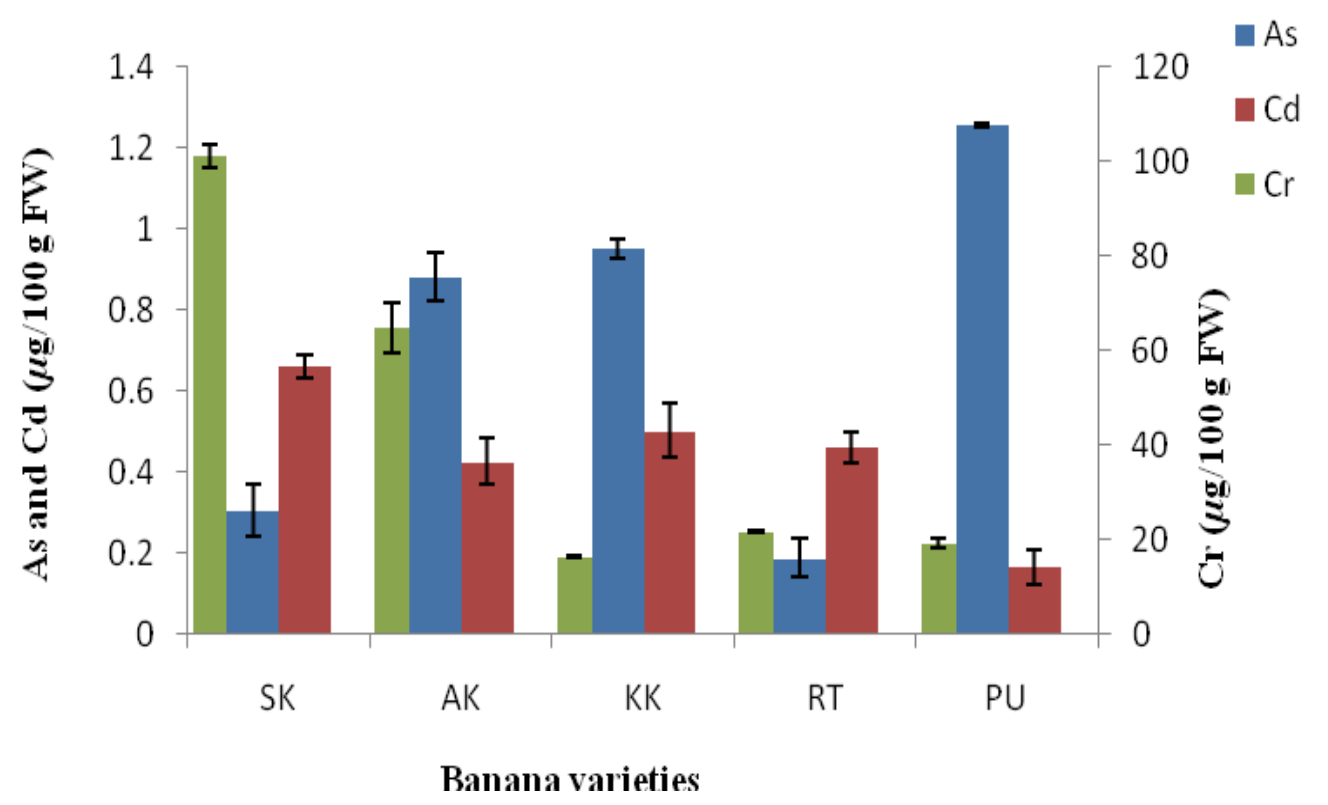

Figure 6 As, Cd and Cr contents of banana varieties 
Proceedings of $2^{\text {nd }}$ International Conference on Food Quality, Safety and Security, Vol. 1, 2018, pp. 17-25

Table 3 Mineral contents of selected banana varieties on fresh weight basis

\begin{tabular}{|c|c|c|c|c|c|}
\hline $\begin{array}{l}\text { Mineral } \\
\text { elements }\end{array}$ & SK & AK & KK & RT & PU \\
\hline & $\mathrm{mg} / 100 \mathrm{~g}$ & $\mathrm{mg} / 100 \mathrm{~g}$ & $\mathrm{mg} / 100 \mathrm{~g}$ & $\mathrm{mg} / 100 \mathrm{~g}$ & $\mathrm{mg} / 100 \mathrm{~g}$ \\
\hline $\mathrm{Na}$ & $2.96 \pm 0.38^{\mathrm{d}}$ & $1.20 \pm 0.18^{\mathrm{e}}$ & $6.36 \pm 0.11^{\mathrm{a}}$ & $5.69 \pm 0.13^{\mathrm{b}}$ & $4.21 \pm 0.01^{\mathrm{c}}$ \\
\hline $\mathrm{Mg}$ & $39.54 \pm 0.67^{\mathrm{bc}}$ & $40.80 \pm 1.04^{b}$ & $37.96 \pm 0.54^{c}$ & $43.09 \pm 0.36^{\mathrm{a}}$ & $35.63 \pm 0.42^{c}$ \\
\hline $\mathrm{K}$ & $490.50 \pm 4.82^{b}$ & $524.91 \pm 14.59^{a}$ & $554.41 \pm 7.50^{\mathrm{a}}$ & $569.75 \pm 15.77^{\mathrm{a}}$ & $487.39 \pm 0.68^{b}$ \\
\hline $\mathrm{Ca}$ & $58.72 \pm 3.17^{\mathrm{a}}$ & $52.24 \pm 1.12^{b}$ & $45.48 \pm 1.60^{\mathrm{c}}$ & $41.09 \pm 3.07^{\mathrm{c}}$ & $61.62 \pm 0.10^{\mathrm{a}}$ \\
\hline $\mathrm{Al}$ & $0.45 \pm 0.02^{\mathrm{b}}$ & $0.82 \pm 0.05^{\mathrm{a}}$ & $0.37 \pm 0.01^{b}$ & $0.43 \pm 0.08^{\mathrm{b}}$ & $0.15 \pm 0.02^{\mathrm{c}}$ \\
\hline $\mathrm{Mn}$ & $3.39 \pm 0.12^{\mathrm{a}}$ & $3.05 \pm 0.03^{b c}$ & $2.95 \pm 0.01^{\mathrm{c}}$ & $3.10 \pm 0.00^{b c}$ & $3.16 \pm 0.02^{b}$ \\
\hline $\mathrm{Fe}$ & $3.63 \pm 0.19^{\mathrm{a}}$ & $2.29 \pm 0.55^{\mathrm{b}}$ & $1.71 \pm 0.04^{\mathrm{b}}$ & $1.91 \pm 0.20^{\mathrm{b}}$ & $1.66 \pm 0.09^{\mathrm{b}}$ \\
\hline $\mathrm{Cu}$ & $0.34 \pm 0.01^{\mathrm{a}}$ & $0.23 \pm 0.01^{b}$ & $0.21 \pm 0.00^{\mathrm{c}}$ & $0.22 \pm 0.00^{\mathrm{bc}}$ & $0.23 \pm 0.00^{\mathrm{b}}$ \\
\hline $\mathrm{Zn}$ & $2.09 \pm 0.03^{\mathrm{a}}$ & $2.10 \pm 0.00^{\mathrm{a}}$ & $1.92 \pm 0.01^{b}$ & $0.48 \pm 0.10^{\mathrm{c}}$ & $0.49 \pm 0.00^{\mathrm{c}}$ \\
\hline $\mathrm{Rb}$ & $2.29 \pm 0.09^{b}$ & $2.69 \pm 0.14^{\mathrm{a}}$ & $1.12 \pm 0.00^{\mathrm{d}}$ & $1.61 \pm 0.04^{\mathrm{c}}$ & $2.42 \pm 0.00^{\mathrm{b}}$ \\
\hline $\mathrm{Sr}$ & $0.35 \pm 0.00^{\mathrm{a}}$ & $0.33 \pm 0.00^{\mathrm{a}}$ & $0.24 \pm 0.01^{b}$ & $0.20 \pm 0.01^{c}$ & $0.22 \pm 0.01^{\mathrm{bc}}$ \\
\hline \multirow[t]{2}{*}{$\mathrm{Ba}$} & $0.63 \pm 0.06^{\mathrm{a}}$ & $0.53 \pm 0.04^{\mathrm{a}}$ & $0.55 \pm 0.04^{\mathrm{a}}$ & $0.39 \pm 0.00^{\mathrm{b}}$ & $0.60 \pm 0.01^{\mathrm{a}}$ \\
\hline & $\mu \mathrm{g} / 100 \mathrm{~g}$ & $\mu \mathrm{g} / 100 \mathrm{~g}$ & $\mu \mathrm{g} / 100 \mathrm{~g}$ & $\mu \mathrm{g} / 100 \mathrm{~g}$ & $\mu \mathrm{g} / 100 \mathrm{~g}$ \\
\hline $\mathrm{Cr}$ & $101.14 \pm 2.62^{\mathrm{a}}$ & $64.74 \pm 5.40^{\mathrm{b}}$ & $16.40 \pm 0.14^{\mathrm{c}}$ & $21.79 \pm 0.17^{\mathrm{c}}$ & $19.22 \pm 0.89^{c}$ \\
\hline $\mathrm{Co}$ & $3.97 \pm 0.01^{\mathrm{a}}$ & $2.78 \pm 0.13^{\mathrm{b}}$ & $2.05 \pm 0.07^{\mathrm{c}}$ & $1.56 \pm 0.36^{\mathrm{d}}$ & $1.69 \pm 0.04^{\mathrm{cd}}$ \\
\hline $\mathrm{Ni}$ & $18.39 \pm 0.29^{\mathrm{a}}$ & $16.43 \pm 0.32^{b}$ & $16.69 \pm 0.80^{\mathrm{ab}}$ & $17.42 \pm 1.23^{\mathrm{ab}}$ & $10.55 \pm 0.53^{\mathrm{c}}$ \\
\hline As & $0.30 \pm 0.09^{\mathrm{bc}}$ & $0.88 \pm 0.05^{\mathrm{ab}}$ & $0.95 \pm 0.02^{\mathrm{ab}}$ & $0.19 \pm 0.04^{c}$ & $1.25 \pm 0.00^{\mathrm{a}}$ \\
\hline $\mathrm{Se}$ & $6.01 \pm 0.71^{\mathrm{a}}$ & $1.51 \pm 0.35^{\mathrm{d}}$ & $4.50 \pm 0.18^{b}$ & $3.30 \pm 0.51^{\mathrm{bc}}$ & $2.76 \pm 0.92^{\mathrm{cd}}$ \\
\hline $\mathrm{Li}$ & $4.78 \pm 0.09 b$ & $5.69 \pm 2.53 \mathrm{a}$ & $4.79 \pm 0.20 b$ & $4.24 \pm 0.96 b$ & $4.95 \pm 0.16 b$ \\
\hline $\mathrm{Be}$ & $0.17 \pm 0.06 a$ & $0.04 \pm 0.01 \mathrm{~b}$ & $0.09 \pm 0.00 \mathrm{~b}$ & $0.09 \pm 0.00 \mathrm{~b}$ & $0.08 \pm 0.01 b$ \\
\hline V & $1.59 \pm 0.61 \mathrm{ab}$ & $1.97 \pm 0.50 \mathrm{ab}$ & $1.59 \pm 0.02 \mathrm{ab}$ & $2.35 \pm 0.61 \mathrm{a}$ & $0.94 \pm 0.01 b$ \\
\hline $\mathrm{Ga}$ & $5.32 \pm 0.25 \mathrm{a}$ & $4.20 \pm 0.14 b c$ & $4.01 \pm 0.12 b c$ & $4.47 \pm 0.61 b$ & $3.56 \pm 0.03 c$ \\
\hline Mo & $5.79 \pm 0.43 a$ & $1.08 \pm 0.07 \mathrm{c}$ & $1.09 \pm 0.06 \mathrm{c}$ & $0.91 \pm 0.11 \mathrm{c}$ & $2.83 \pm 0.42 b$ \\
\hline $\mathrm{Cd}$ & $0.66 \pm 0.03 a$ & $0.43 \pm 0.06 \mathrm{ab}$ & $0.50 \pm 0.07 \mathrm{ab}$ & $0.46 \pm 0.09 \mathrm{ab}$ & $0.16 \pm 0.06 c$ \\
\hline $\mathrm{Bi}$ & $0.01 \pm 0.00 \mathrm{~b}$ & $0.01 \pm 0.00 \mathrm{~b}$ & $0.01 \pm 0.00 \mathrm{~b}$ & $0.03 \pm 0.00 \mathrm{a}$ & $0.01 \pm 0.01 b$ \\
\hline
\end{tabular}

Data represent the mean values \pm SD $(n=3)$ of three independent experiments. Means followed by the same letters in a row are not significantly different at a particular probability level by Duncan's multiple range test.

The values obtained for mineral elements in these banana varieties confirmed the findings of many authors such as Deraniyagala et al. (1994), Wall (2006) and Longvah et al. (2017). Though they were different varieties of Musa spp. from different countries, similar range of values had been resulted. RDA/ Adequate Intake (AI) of minerals can be compared with mineral contents of banana assuming complete absorption to the body. Banana was a reasonably good source of $\mathrm{Cr}, \mathrm{Fe}, \mathrm{Mg}, \mathrm{Mn}, \mathrm{Zn}, \mathrm{Cu}$ and $\mathrm{K}$ which showed closer values to RDA /AI. RDA of $\mathrm{Cr}, \mathrm{Fe}, \mathrm{Mg}, \mathrm{Mn}, \mathrm{Zn}, \mathrm{Cu}$ and $\mathrm{K}$ for a person aged 19 - 70 years could be solely met by intake of about $19-213$ g, $220-1084 \mathrm{~g}, 0.7-1.2 \mathrm{~kg}, 53-78 \mathrm{~g}, 0.4-2.3 \mathrm{~kg}, 428 \mathrm{~g}, 825$ - $964 \mathrm{~g}$ of studied banana varieties respectively. The inorganic arsenic lower limit on the benchmark dose for a $0.5 \%$ increased incidence of lung cancer $\left(\mathrm{BMDL}_{0.5}\right.$ ) was determined from epidemiological studies to be $3.0 \mu \mathrm{g} / \mathrm{kg}$ of body weight per day (JECFA, 2010). According to that, lower limit of As for a person who weighs $60 \mathrm{~kg}$ is $180 \mu \mathrm{g} / \mathrm{d}$. Provisional tolerable monthly intake of $\mathrm{Cd}$ is $25 \mu \mathrm{g} / \mathrm{kg}$ body weight (JECFA, 2010). Based on that, provisional tolerable daily intake of $\mathrm{Cd}$ for a person who weighs $60 \mathrm{~kg}$ is $50 \mu \mathrm{g}$. When these recommended tolerable intakes are considered, 
despite the fact that banana contained substantial amount of As and $\mathrm{Cd}$, they were still far below the harmful levels.

\section{Conclusion}

This study was carried out to assess and to identify the significance of the proximate and mineral composition of selected five varieties of banana grown and consumed commonly in Sri Lanka namely, Seeni kesel, Ambul kesel, Kolikuttu, Rathambala and Puwalu. The results of the study indicate that banana is a good source of nutrients: carbohydrates and minerals (especially $\mathrm{Cr}, \mathrm{Fe}, \mathrm{Mg}, \mathrm{Mn}, \mathrm{Zn}, \mathrm{Cu}$ and $\mathrm{K}$ ). Comparatively, Seeni kesel contained higher ash and carbohydrate contents than other studied banana varieties while Kolikuttu and Puwalu were comprised of the highest protein and the highest fat contents respectively. Generally, Seeni kesel is superior in studied nutrients than other varieties in accordance with all the results of this study.

Among greatly concerned heavy metals, $\mathrm{Cr}$ and $\mathrm{Cd}$ contents were comparatively higher in Seeni kesel than other examined varieties and the highest As content was found in Puwalu which might be resulted by malpractices of cultivation, artificial ripening, packaging and storage. Moreover, these results suggest that consumption of sufficient amount of banana grown under safe farming practices and make available for consumption under safe ripening techniques could beneficially contribute to the nutritional requirement of human. Furthermore, study of the bioavailability of nutrients would be beneficial in food consumption surveys, diet recommendation and in mediating nutrient deficiency, nutrient adequacy and nutrient toxicity of populations.

\section{Acknowledgements}

The authors express deep sense of gratitude to United Nations Environment Programme (UNEP) and Food and Agriculture Organization (FAO) for the financial support. Plant Genetic Resource Centre (PGRC), Department of Agriculture; Department of Geology, Faculty of Science, University of Peradeniaya and Department of Applied Nutrition, Faculty of Livestock, Fisheries and Nutrition, Wayamba University are gratefully acknowledged for the contribution in technical support to carry out the research successfully.

\section{References}

AACC, 2003, Approved methods of the AACC, St Paul, MN: American Association of Cereal Chemists, 10th ed.

Ajayi, A. R and Mbah, G. O., 2007, Identification of indigenous ripening technologies of banana and plantain fruits among women-marketers in Southeastern Nigeria. Journal of Agriculture, Food, environment and Extension, 6(2), 60-66.

AOAC, 2000, Official methods of analysis of AOAC. International 17th edition, Gaithersburg, MD, USA Association of Analytical Communities.

Asif, M., 2012, Physico-chemical properties and toxic effect of fruit-ripening agent calcium carbide. Annals of tropical medicine and public health, 5(3), 150-160.

Banadda, N., Namawejje, H., Ayaa, F., Kigozi, J. B and Sendagi, S., 2011, Diffusive flux modeling of lead migration from black polythene bags into food: A case study of green bananas (Matooke). African journal of Food science, 5(5), 313-319.

de la Rocha, S. R., Sanchez-Muniz, F. J., Gómez-Juaristi, M. and Marín, M. L., 2009, Trace elements determination in edible seaweeds by an optimized and validated ICP-MS method. J. Food Comp. Anal., 22(4), 330-336.

Deraniyagala, S. A., Mudalige, K. T., Anula, H. M. and Jamburuthugoda, M. Y. P. R., 1994, Some micronutrient and macronutrient contents of some Sri Lanka food varieties. Vidyodaya J. of sa., 5(1), 93 - 102.

Ekanayake, E. M. D. S. N., Samarasinghe, W. L. G. and Randeni, R. A. V. K., 2001. An unrecorded banana cultivar from Sri Lanka. Ann Sri Lanka Dept Agric., 3, 37-42. 
Hettiaratchi, U. P. K., Ekanayake, S. and Welihinda, J., 2011, Chemical compositions and glycemic responses to banana varieties. International journal of food sciences and nutrition, 62(4), pp.307-309.

Institute of Medicine, 2005, Dietary Reference Intakes for Energy, Carbohydrate, Fiber, Fat, Fatty Acids, Cholesterol, Protein, and Amino Acids. Washington, DC, The National Academies Press.

Longvah, T., Ananthan, R., Bhaskarachary, K. and Venkaiah, K., 2017, Indian Food Composition Tables. National Institute of Nutrition, Hyderabad.

Ng, J. C., 2011., Evaluation of certain contaminants in food: Seventy-second report of the Joint FAO/WHO Expert Committe on Food Additives, World Health Organization, Vol. 959, No. 959.

Sobukola, O. P., Adeniran, O. M., Odedairo, A. A. and Kajihausa, O. E., 2010, Heavy metals levels of some fruits and leafy vegetables from selected markets in Lagos, Nigeria. African Journal of Science, 4(2), 389-393.

Temple, N. J., 2000, Antioxidants and disease: more questions than answers. Nutr Res., 20, 449-59.

Wall, M. M., 2006, Ascorbic acid, vitamin A, and mineral composition of banana (Musa sp.) and papaya (Carica papaya) cultivars grown in Hawaii. Journal of Food Composition and analysis, 19(5), 434-445.

Willett, W. C., 1995, Diet, nutrition, and avoidable cancer. Environ Health Perspect., 103(8), 165-70. 